Original Research Paper

\title{
Seismic Assessment of Non-Seismically Designed Reinforced Concrete Frames with Core Walls
}

\author{
${ }^{1}$ Taek-Hyun Lee, ${ }^{2}$ Ki-Bong Choi and ${ }^{3}$ Taher Abu-Lebdeh \\ ${ }^{1}$ Ist Structural Engineering, Seoul, Korea \\ ${ }^{2}$ Department of Architectural Engineering, Gachon University, Seongnam, Korea \\ ${ }^{3}$ Department of Civil Engineering, North Carolina A and T State University, Greensboro, NC, USA
}

Article history

Received: 24-07-2014

Revised: 02-12-2014

Accepted: 05-12-2014

Corresponding Author: Ki-Bong Choi,

Department of Architectural

Engineering, Gachon

University, Seongnam, Korea

Email:kbchoi@gachon.ac.kr

\begin{abstract}
This study examines the seismic performance of four nonseismically designed reinforced concrete structures with core walls and proposes proper rehabilitation methods. The structures were selected based on the height of the structures, occupancy levels and floor plans. The seismic assessment results were compared based on the performance of the structures before rehabilitation and after rehabilitation. The results indicate that most of the structures are unsatisfactory in terms of their failure to reach a level of life safety. Three types of rehabilitation methods, i.e., reinforcement walls, braces and columns, were applied to assess the seismic performance of the four case studies. The two-phase seismic assessments of the rehabilitated structures were conducted according to current provisions used in Korea.
\end{abstract}

Keywords: Core Wall, Reinforced Concrete (RC) Frame, Non-Seismically Designed, Seismic Assessment

\section{Introduction}

This study examines four cases of Reinforced Concrete (RC) frames that have core walls and were designed before 1988 without seismic considerations. The seismic performance of the selected structures was assessed according to existing design codes used in Korea. Recommendations regarding proper rehabilitation methods are offered based on the seismic assessment results. The study set selected for this study is a total of 320 building configurations. The configurations were chosen based on the height, occupancy or use and floor plan of the buildings.

$\mathrm{RC}$ frames with core walls were used in several of the structural components, including stair sections and elevator sections. Even if the RC frame was designed originally as a non-seismically designed structure, these core walls would still enhance the resistance to lateral loads and would affect the seismic performance of the structures. However, there is uncertainty with respect to the optimal location and size of the core wall. In order to evaluate these non-seismically designed structures in terms of their seismic performance, two structures with a core wall in the middle and two structures with a core wall on the side have been selected for this study. The results are compared before and after reinforcing the structures.
The literature provides several examples of seismic assessment research. Kang (2011) conducted a seismic assessment of a complex house with a bearing wall by using pushover analysis according to seismic design guidelines. Kim (2011) conducted nonlinear analysis of existing reinforced concrete structures and proposed an appropriate rehabilitation method using seismic design strength after evaluating the desired seismic capacity of the structures. Lee (2013) investigated seismic assessment and rehabilitation methods for mid-rise RC structures with core walls. The structures were rehabilitated using walls, columns and braces. Adebar and White (2002; Adebar, 2005; 2008) structures with core walls using response spectrum analysis.

Also, several countries, including Korea and the United States, have proposed seismic assessment guidelines for existing RC structures. In Korea (the focus of this study's case structures), two provisions are available for the seismic performance assessment of existing structures: The Korea Infrastructure Safety and Technology Corporation (KISTEC) (KISC, 2011) guidelines and the National Fire Management Agency (NEMA) (NEMA, 2012) guidelines. These Korean guidelines were developed based on the Federal Emergency Management Agency (FEMA) (FEMA, 
1997; 2000) and American Society of Civil Engineers (ASCE) guidelines in the United States (ASCE, 2003; 2006). The selected seismic assessment method used for this study is the KISTEC guidelines, which include timeintensive analyses compared to the other guidelines However, despite the time factor, the structural analysis and structural performance of individual members inherent of the (KISC, 2011) guidelines lead to precise results and, therefore, these guidelines have been selected for this study.

Seismic assessments were conducted for the selected structures before and after rehabilitation. The first evaluation is a preliminary seismic assessment and the second evaluation is a detailed seismic assessment. The seismic capacity of a structure might be computed conservatively in the first assessment based on the properties and proposed equations in the existing provisions. If the results from the first assessment do not meet the required seismic capacity, then the second seismic assessment might be recommended. For the detailed second seismic assessment, the selected structures are evaluated based on fundamental material information and detailed structural analysis results. If the performance does not meet the desired seismic performance in the second assessment, the implication is that the deficient member (s) in the structures require rehabilitation or further analysis, such as nonlinear analysis.

Loads are composed of a gravity load and an earthquake load. The structural behavior is categorized as either deformation-controlled action or forcecontrolled action. In this study, different load combinations were considered for each controlled action. The expected strength for deformationcontrolled action, $Q_{C E}$, is defined as the mean value of the resistance of a component at the deformation level that is anticipated for a population of similar components. This parameter includes consideration of the variability in material strength as well as strainhardening and plastic section development. The design strengths for force-controlled actions, $Q_{C L}$, are taken as the lower-bound strength, considering all the coexisting actions in the element (KISC, 2011).

Unless other procedures are specified in the standard, the procedures outlined in KBC 2009 to calculate nominal strength and mean strength were used in this study. For all cases, the strength reduction factor was taken as unity in the assessment of the existing structures. For the deformation-controlled action, the strength of the RC members was computed using the equations found in KBC 2009. To consider the difference between nominal strength and mean strength, the yield strength values of the reinforcement and concrete compressive strength were determined by multiplying each strength value by 1.2 (KISC, 2011).

Table 1-3 present the expected material properties, the shear stress values for columns with various failure modes and shear walls with respect to the location of the columns, respectively. The presented information was used to determine the strength values for each member of the RC structures.

The final assessment determines the Demand and Capacity Ratio (DCR) of the structures. Demand is the shear stress that is due to the seismic load. Capacity is computed as the summation of the shear resistance. Equation 1 shows the DCR values for a RC structure. Table 4 presents the performance level with respect to the DCR values:

$$
D C R_{i}=\frac{S_{D s}-W-_{\gamma i}}{C_{i}}
$$

Where:

$S_{D S}=$ The spectral response acceleration parameter at short periods

$W=$ The total weight of the structure and

$\gamma_{i}=$ The shear distribution coefficient.

Table 1. Expected or lower bound material properties (KISC, 2011)

\begin{tabular}{|c|c|c|c|c|}
\hline \multirow[b]{2}{*}{ Year strength } & \multicolumn{2}{|l|}{ Before 1970} & \multicolumn{2}{|l|}{ 1971-1988 } \\
\hline & Lower bound & Average & Lower bound & Average \\
\hline Concrete strength $\left(f_{c k}, \mathrm{MPa}\right)$ & 13 & 15 & 15 & 18 \\
\hline Yield strength of reinforcement $\left(f_{v}, \mathrm{MPa}\right)$ & 240 & 300 & 240 & 300 \\
\hline Year strength & $1988-2000$ & After 2001 & & \\
\hline Concrete strength $\left(f_{c k}, \mathrm{MPa}\right)$ & 18 & 21 & 21 & 24 \\
\hline Yield strength of reinforcement $\left(f_{y}, \mathrm{MPa}\right)$ & 300 & 375 & 300 & 375 \\
\hline
\end{tabular}

Table 2. Average shear stress for columns (KISC, 2011)

$$
\text { Construction year (MPa) }
$$

\begin{tabular}{llllll} 
Year classification of column & & Before 1970 & $1971-1987$ & $1988-2000$ & After 2001 \\
\hline Shear failure $v_{s c}$ & Short column $h_{o} / D<2.0$ & 1.17 & 1.23 & 1.34 & 1.41 \\
Flexural failure $v_{f c}$ & Intermediate column $2.0<h_{o} / D<6.0$ & 0.86 & 0.9 & 0.98 & 1.03 \\
\hline
\end{tabular}


Table 3. Shear stress of shear wall with respect to condition of column (KISC, 2011)

Shear wall with columns on both sides

Table 4. DCR values for performance level of rc structure (KISC, 2011)

\begin{tabular}{ll}
\hline DCR value & Performance level \\
\hline DCR $\leq 0.5$ & Immediate Occupancy (IO) \\
$0.5<$ DCR $<0.75$ & Life Safety (LS) \\
$0.75<$ DRC $\leq 1.0$ & Collapse Prevention (CP) \\
$1.0<$ DCR & Collapse \\
\hline
\end{tabular}

\section{Seismic Assessment before Rehabilitation}

The selected structures were built in 1986 and 1987. Table 5 presents basic information about these four structures, MC-1, MC-2, CC-1 and CC-2. The structures are identified according to the location of the core and the ratio of the core area to the total area. For example, MC-1 indicates that the core is located in the middle of the structure and is below $10 \%$ of the ratio of the core area to the total area. CC similarly indicates that the core is in the corner of the structure.

Figure 1 presents the floor plans for each of the structures. The structures were made with $\mathrm{RC}$ with core walls around the stairs and elevators.

\section{Seismic Assessments of Selected Structures}

\section{First Seismic Assessment}

In the first assessment of the four types of $\mathrm{RC}$ structures, the DCRs were used to determine seismic performance, as shown in Equation 2:

$\mathrm{DCR}_{\mathrm{i}}=\frac{\mathrm{S}_{\mathrm{Ds}}-\mathrm{W}-\gamma_{\mathrm{i}}}{\sum V_{i}}$

MC-1 is a 7-storey building constructed with a RC frame structure with a shear wall in the middle. This structure falls in the site classification of $S_{C}$ and seismic Zone 1. Therefore, the spectral response acceleration parameter at short periods, $S_{D S}$, is 0.43 . The weight of each storey is $2343.6 \mathrm{kN}$, which is the floor area multiplied by $10 \mathrm{kN} / \mathrm{m}^{2}$. The demand values were computed using the seismic shear coefficient $\left(\gamma_{i}\right)$ and spectral response acceleration parameter at short periods $\left(S_{D S}\right)$. Table 6 shows the demand values for the MC-1 structure determined from Equation 2.

The shear stress values vary with respect to the aspect ratio of the columns and construction year. Most columns were classified as an intermediate column, except $\mathrm{C} 1, \mathrm{C} 5, \mathrm{C} 13$ and $\mathrm{C} 16$ in the MC-1 structure. MC1 was constructed around 1987. The average shear strength values for the short, intermediate and long columns in MC-1 are $1.23 \mathrm{MPa}, 0.74$ and $0.47 \mathrm{MPa}$, respectively. The average shear stress values are $3 \mathrm{MPa}$, $2 \mathrm{MPa}$ and $1 \mathrm{MPa}$ for a shear wall with two columns, a shear wall with a column on one side and a shear wall without a column, respectively.

Table 7 presents first seismic assessment results in terms of the performance levels based on the DCRs for the MC-1 structure.

The highest DCR values for MC- 1 are 0.98 for the $y$ direction and 0.9 for the $\mathrm{x}$-direction for the first floor. These values indicate that the structure is at a level of collapse prevention.

In the same manner, the remaining structures (MC-2, CC-1 and CC-2) were evaluated for the first seismic assessment. Figure 2 shows the seismic performance levels for all four structures.

Figure 2 shows that the DCR value for CC- 1 is 0.88 for both the $\mathrm{x}$ - and $\mathrm{y}$-direction sat the level of collapse prevention. The DCR values for $\mathrm{MC}-2$ and $\mathrm{CC}-2$ are 0.55 for the $\mathrm{x}$-direction at the level of life safety, but 0.81 for the $y$-direction at the level of collapse prevention. The DCR value for MC- 1 with a core area of $2.4 \%$ is 0.9 for the $\mathrm{x}$-direction at the level of collapse prevention and 0.98 for the $y$-direction. The DCR value for CC- 1 with a core area of $5.6 \%$ is 0.88 for both the $\mathrm{x}$-direction and $\mathrm{y}$ direction at the level of collapse prevention.

MC-2 and CC-2 have over $10 \%$ core area compared to the total areas of these two structures. 


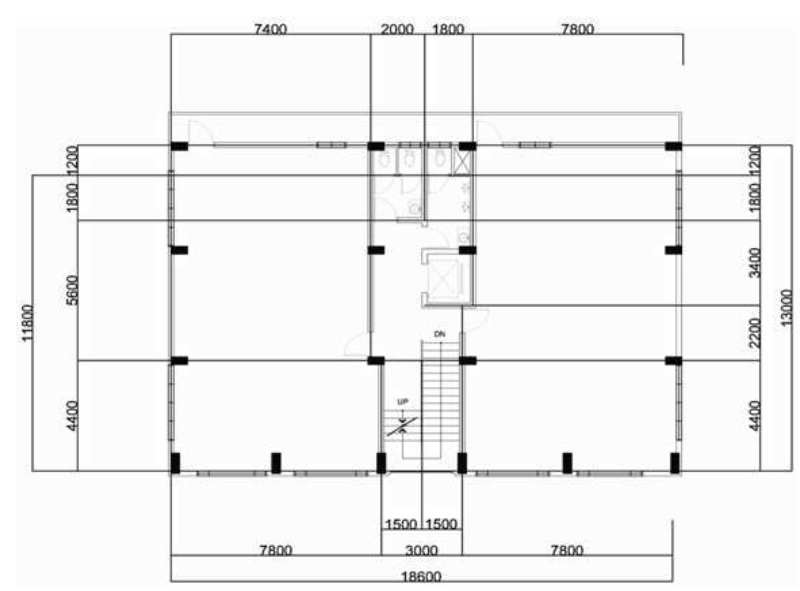

(a)

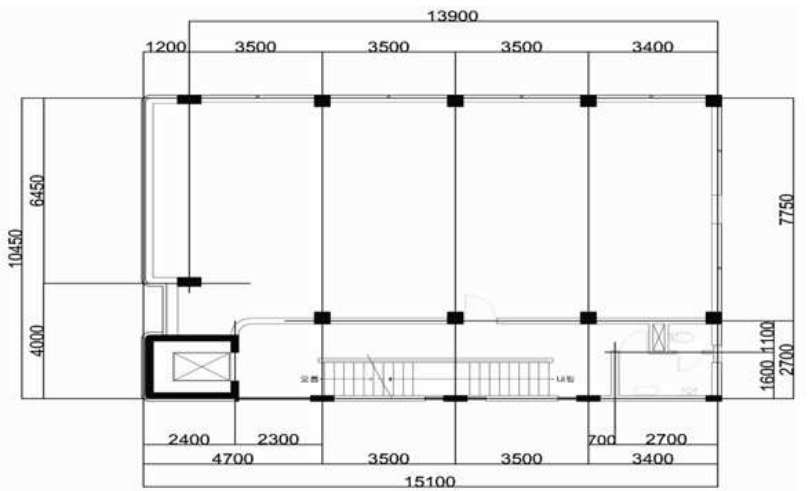

(c)

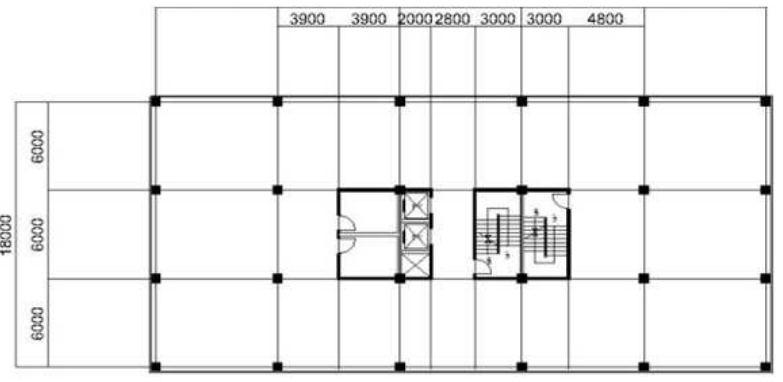

(b)

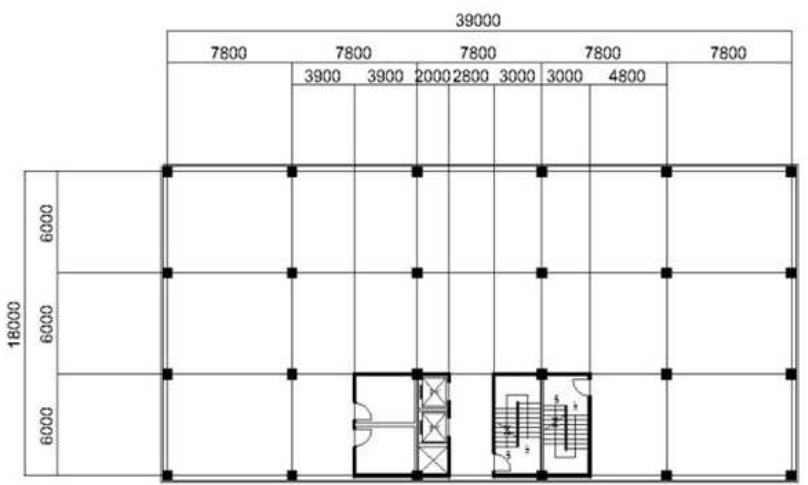

(d)

Fig. 1. Floor plans of selected structures, (a) Floor plan for MC-1, (b) Floor plan for MC-2, (c) Floor plan for CC-1, (d) Floor plan for CC-2

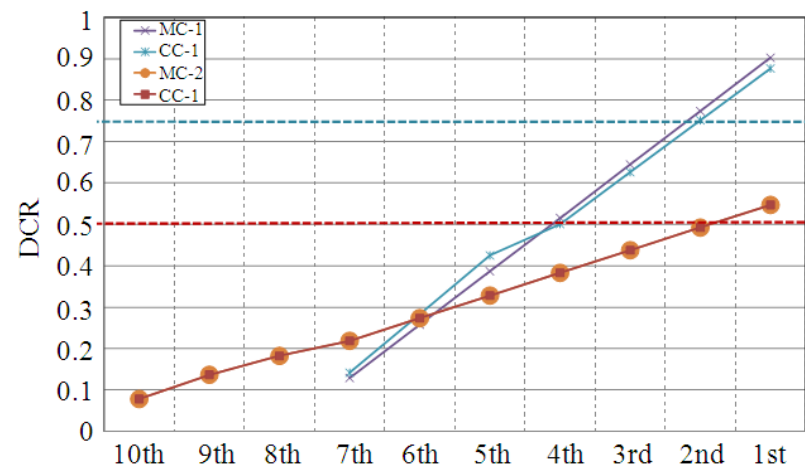

(a)

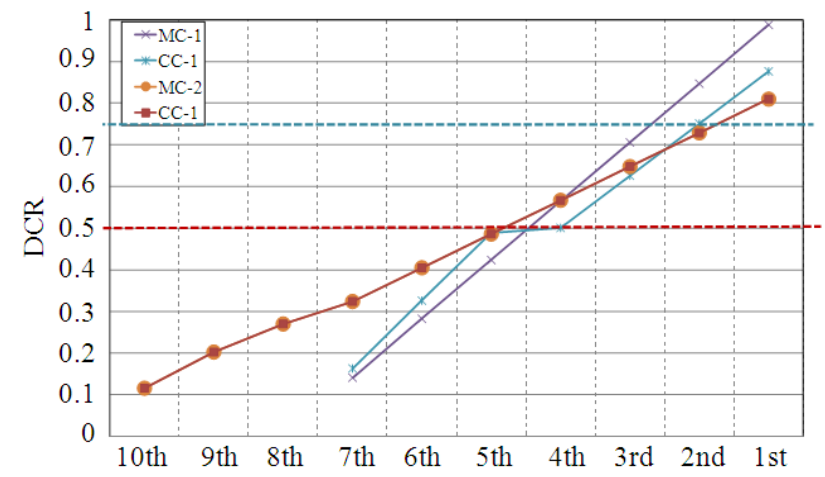

(b)

Fig. 2. First seismic assessment results for each structure

Table 5. Selected structures

\begin{tabular}{lllll}
\hline Structure ID & MC-1 & MC-2 & CC-1 & CC-2 \\
\hline Gross floor area $\left(\mathrm{m}^{2}\right)$ & 1640.52 & 7020 & 1024.1 & 7020 \\
Number of storeys & 7 -storey & 10 -storey & 7 -storey & 10 -storey \\
Maximum height $(\mathrm{m})$ & 23.1 & 33.2 & 25.2 & 33.2 \\
Occupancy or use & Facility & Office & Hospital & Office \\
Location of core & Middle & Middle & Corner & Corner \\
Ratio of core area to total area & $2.40 \%$ & $10 \%$ & $5.60 \%$ & $10 \%$ \\
\hline
\end{tabular}


Table 6. Demand values for MC-1

\begin{tabular}{llllllll}
\hline Storey & Height $h_{i}, \mathrm{~mm}$ & Floor area $\left(\mathrm{m}^{2}\right)$ & Weight $\left(w_{i}\right),(\mathrm{kN})$ & $w_{i}{ }^{*} h_{i}$ & cumulated $w_{i}{ }^{*} h_{i}$ & $\gamma_{\mathrm{i}}$ & Demand $(\mathrm{kN})$ \\
\hline 7th & 3300 & 234.36 & 2343.6 & 7733880 & 7733880 & 0.142 & 475.081 \\
6th & 3300 & 234.36 & 2343.6 & 7733880 & 15467760 & 0.285 & 950.162 \\
5th & 3300 & 234.36 & 2343.6 & 7733880 & 23201640 & 0.428 & 1425.24 \\
4th & 3300 & 234.36 & 2343.6 & 7733880 & 30935520 & 0.571 & 1900.32 \\
3rd & 3300 & 234.36 & 2343.6 & 7733880 & 38669400 & 0.714 & 2375.40 \\
2nd & 3300 & 234.36 & 2343.6 & 7733880 & 46403280 & 0.857 & 2850.48 \\
1st & 3300 & 234.36 & 2343.6 & 7733880 & 54137160 & 1.000 & 3325.56 \\
\hline
\end{tabular}

Table 7. First seismic assessment results for MC-1

\begin{tabular}{|c|c|c|c|c|c|}
\hline DCR for each floor & Direction & Demand, $(k N)$ & Capacity, $(k N)$ & DCR & Performance level \\
\hline \multirow[t]{2}{*}{7 th } & $\mathrm{X}$ & 475.0812 & 3686.49 & 0.12 & $\mathrm{IO}$ \\
\hline & $\mathrm{Y}$ & 475.0812 & 3366.49 & 0.14 & $\mathrm{IO}$ \\
\hline \multirow[t]{2}{*}{ 6th } & $\mathrm{X}$ & 950.1624 & 3686.49 & 0.25 & $\mathrm{IO}$ \\
\hline & $\mathrm{Y}$ & 950.1624 & 3366.49 & 0.28 & IO \\
\hline \multirow[t]{2}{*}{5 th } & $\mathrm{X}$ & 1425.244 & 3686.49 & 0.38 & IO \\
\hline & $\mathrm{Y}$ & 1425.244 & 3366.49 & 0.42 & IO \\
\hline \multirow[t]{2}{*}{4 th } & $\mathrm{X}$ & 1900.325 & 3686.49 & 0.51 & IO \\
\hline & $\mathrm{Y}$ & 1900.325 & 3366.49 & 0.56 & $\mathrm{IO}$ \\
\hline \multirow[t]{2}{*}{$3 \mathrm{rd}$} & $\mathrm{X}$ & 2375.406 & 3686.49 & 0.64 & $\mathrm{LS}$ \\
\hline & $\mathrm{Y}$ & 2375.406 & 3366.49 & 0.70 & LS \\
\hline \multirow[t]{2}{*}{ 2nd } & $\mathrm{X}$ & 2850.487 & 3686.49 & 0.77 & $\mathrm{LS}$ \\
\hline & $\mathrm{Y}$ & 2850.487 & 3366.49 & 0.84 & $\mathrm{LS}$ \\
\hline \multirow[t]{2}{*}{1 st } & $\mathrm{X}$ & 3325.568 & 3686.49 & 0.90 & $\mathrm{CP}$ \\
\hline & $\mathrm{Y}$ & 3325.568 & 3366.49 & 0.98 & $\mathrm{CP}$ \\
\hline
\end{tabular}

Note: IO is immediate occupancy; LS is life safety and CP is collapse prevention

The DCR values for those structures are 0.55 for the $\mathrm{x}$-direction at the level of life safety, but 0.81 for the $\mathrm{y}$-direction at the level of collapse prevention. These results are due to the non-seismically designed structure and the location of the cores.

The results of the first seismic assessment indicate that the larger the core area, the better the seismic performance with an in crease in DCR values. However, when the core area is less than $10 \%$ of the total area, the effects are negligible. Most of the structures built between 1970 and into the $1980 \mathrm{~s}$ have a small core area. Therefore, rehabilitation is required for those structures.

If the structure is large enough to need an elevator, the core areas, such as the E/V and emergency stairs, are better protected and the core wall plays a role in the structure's internal seismic resistance. The performance levels of MC-2 and CC-2 with $10 \%$ core areas likewise depend on the locations of the cores. However, according to the existing provision specifications, the walls in these two structures do not meet the desired performance level (life safety) due to the skewed location of the walls. The first seismic assessment, as a preliminary assessment, disqualified the desired performance level (i.e., level of life safety), so the first assessment was followed by a second assessment. In fact, none of the selected structures met the minimum desired performance (life safety). In addition, the core location in the structure was not considered in the first assessment. Therefore further assessment was required.

\section{Second Seismic Assessment}

The second assessment was conducted based on the results from the structural analysis for each member. The DCR values for each member were used to determine the performance level. Ductility coefficients $(m)$ were used to determine the structural performance level. Table 8 shows the DCR values for the vertical members in the MC-1 structure.

Table 9 shows the DCR values with respect to the desired performance level and the axially distributed load ratios.

In the second assessment, when each member satisfies the performance level based on the DCR values that correspond to each performance level and when each member carries over $80 \%$ axial load, the structure is considered to qualify for the desired performance level. In the same manner, the remaining structures were assessed and the results are presented in Fig. 3.

MC-1 and CC-1 are 7-storey buildings with core areas of 2.4 and $5.6 \%$, respectively. The second seismic performance assessment results for each of these structures indicate that the performance levels are collapse prevention and near collapse, respectively. These results are the same as or worse. In particular, CC-1 has a core located on one side and the large core area of CC-1 was adversely affected in terms of its seismic performance. The minimum performance level, life safety, was not attained for these two structures, even in the second assessment. 
Taek-Hyun Lee et al. / American Journal of Applied Sciences 2014, 11 (11): 1892.1903 DOI: $10.3844 /$ ajassp.2014.1892.1903

\begin{tabular}{|c|c|c|c|c|c|c|c|c|}
\hline \multirow[b]{2}{*}{ Type } & \multirow[b]{2}{*}{ ID } & \multirow{2}{*}{$\begin{array}{l}\text { Axial load } \\
P(k N)\end{array}$} & \multicolumn{3}{|l|}{ Demand } & \multicolumn{3}{|l|}{ Capacity } \\
\hline & & & $M_{u y}(k N-m)$ & $M_{u z}(k N-m)$ & $V_{u}(\mathrm{kN})$ & $M_{e y}(k N-m)$ & $M_{e z}(k N-m)$ & $V_{e}(k N)$ \\
\hline \multirow[t]{16}{*}{ Column } & C31 & 1543.900 & 96.94 & 30.76 & 29.38 & 43.07 & 36.496 & 245.46 \\
\hline & C32 & 1927.000 & 79.53 & 24.53 & 24.20 & 51.69 & 43.795 & 391.30 \\
\hline & C33 & 2773.800 & 131.10 & 55.87 & 40.85 & 38.03 & 15.663 & 244.91 \\
\hline & C34 & 601.4500 & 8.21 & 8.81 & 2.49 & 51.97 & 94.037 & 280.99 \\
\hline & C35 & 854.680 & 76.35 & 110.68 & -23.14 & 86.24 & 205.420 & 378.63 \\
\hline & C36 & 1335.300 & 44.66 & 110.42 & -13.53 & 53.12 & 206.970 & 378.30 \\
\hline & C37 & 1322.700 & 14.58 & 91.41 & 4.42 & 15.12 & 165.190 & 378.55 \\
\hline & C38 & 1343.400 & 40.89 & 91.67 & 12.39 & 78.25 & 154.300 & 375.77 \\
\hline & C39 & 1514.100 & 18.98 & 22.44 & -5.75 & 122.10 & 98.856 & 412.08 \\
\hline & $\mathrm{C} 40$ & 1673.600 & 62.74 & 19.24 & -19.01 & 134.30 & 108.740 & 398.84 \\
\hline & C41 & 689.750 & 106.76 & 38.78 & 32.35 & 205.70 & 92.495 & 381.94 \\
\hline & C42 & 1470.800 & 66.44 & 6.48 & 20.13 & 155.20 & 22.405 & 373.68 \\
\hline & $\mathrm{C} 43$ & 41.519 & 61.64 & 61.56 & -18.68 & 74.75 & 120.970 & 309.32 \\
\hline & C44 & 439.740 & 13.39 & 58.48 & -4.06 & 121.50 & 93.898 & 320.64 \\
\hline & $\mathrm{C} 45$ & 644.170 & 8.62 & 73.39 & 2.61 & 88.63 & 125.960 & 325.59 \\
\hline & C46 & 891.100 & -56.53 & 46.78 & 17.13 & 114.80 & 83.999 & 337.70 \\
\hline \multirow[t]{3}{*}{ Wall } & W1 & 2402.200 & 732.25 & 0.00 & 314.43 & 300.30 & 0.000 & 223.84 \\
\hline & W2 & 2311.800 & 4680.30 & 0.00 & 2116.50 & 491.90 & 0.000 & 318.00 \\
\hline & W3 & 2829.600 & 1313.90 & 0.00 & 361.83 & 289.90 & 0.000 & 223.84 \\
\hline
\end{tabular}

Table 9. Desired performance assessment for MC-1

\begin{tabular}{|c|c|c|c|c|c|c|c|c|c|}
\hline \multirow[b]{2}{*}{ ID } & \multicolumn{4}{|c|}{ DCR level } & \multicolumn{4}{|c|}{ Desired performance } & \multirow{2}{*}{$\begin{array}{l}\text { Axially } \\
\text { distributed } \\
\text { load ratio }\end{array}$} \\
\hline & IO & LS & $\mathrm{CP}$ & $\mathrm{NC}$ & LS & $\mathrm{CP}$ & $\mathrm{NC}$ & $\mathrm{P},(\mathrm{kN})$ & \\
\hline$\overline{\mathrm{C} 31}$ & 1.77 & 1.77 & 1.18 & 0.11 & $\mathrm{NG}$ & $\mathrm{NG}$ & $\mathrm{OK}$ & -1811.29 & LS: $70 \%$ \\
\hline $\mathrm{C} 32$ & 0.72 & 0.72 & 0.48 & 0.07 & $\mathrm{OK}$ & $\mathrm{OK}$ & $\mathrm{OK}$ & -2083.48 & $(\mathrm{NG})$ \\
\hline $\mathrm{C} 33$ & 1.80 & 1.80 & 1.20 & 0.02 & NG & NG & $\mathrm{OK}$ & -1154.94 & \\
\hline C34 & 1.05 & 1.05 & 0.70 & 0.63 & NG & OK & OK & -1668.06 & CP: 77\% \\
\hline $\mathrm{C} 35$ & 0.64 & 0.64 & 0.43 & 0.23 & OK & OK & $\mathrm{OK}$ & -1599.57 & $(\mathrm{NG})$ \\
\hline $\mathrm{C} 36$ & 0.70 & 0.70 & 0.47 & 0.23 & OK & OK & OK & -1599.96 & \\
\hline $\mathrm{C} 37$ & 0.62 & 0.62 & 0.41 & 0.14 & OK & $\mathrm{OK}$ & $\mathrm{OK}$ & -1560.09 & NP: $89 \%$ \\
\hline $\mathrm{C} 38$ & 0.66 & 0.66 & 0.44 & 0.14 & $\mathrm{OK}$ & $\mathrm{OK}$ & $\mathrm{OK}$ & -1582.66 & $(\mathrm{OK})$ \\
\hline C39 & 0.59 & 0.59 & 0.39 & 0.38 & OK & $\mathrm{OK}$ & $\mathrm{OK}$ & -1336.83 & \\
\hline $\mathrm{C} 40$ & 0.58 & 0.58 & 0.39 & 0.37 & OK & $\mathrm{OK}$ & $\mathrm{OK}$ & -1287.14 & \\
\hline $\mathrm{C} 41$ & 0.65 & 0.65 & 0.43 & 0.05 & $\mathrm{OK}$ & $\mathrm{OK}$ & $\mathrm{OK}$ & -1365.54 & \\
\hline $\mathrm{C} 42$ & 0.64 & 0.64 & 0.42 & 0.02 & $\mathrm{OK}$ & $\mathrm{OK}$ & $\mathrm{OK}$ & -1351.20 & \\
\hline $\mathrm{C} 43$ & 0.59 & 0.59 & 0.40 & 0.33 & $\mathrm{OK}$ & $\mathrm{OK}$ & $\mathrm{OK}$ & -933.65 & \\
\hline $\mathrm{C} 44$ & 0.52 & 0.52 & 0.35 & 0.24 & $\mathrm{OK}$ & $\mathrm{OK}$ & $\mathrm{OK}$ & -927.45 & \\
\hline $\mathrm{C} 45$ & 0.68 & 0.68 & 0.46 & 0.15 & OK & $\mathrm{OK}$ & $\mathrm{OK}$ & -937.78 & \\
\hline $\mathrm{C} 46$ & 0.65 & 0.65 & 0.43 & 0.10 & OK & $\mathrm{OK}$ & $\mathrm{OK}$ & -930.34 & \\
\hline W1 & 5.73 & 4.77 & 3.58 & 3.01 & NG & $\mathrm{NG}$ & $\mathrm{NG}$ & -859.03 & \\
\hline W2 & 4.94 & 4.12 & 3.09 & 3.10 & NG & $\mathrm{NG}$ & $\mathrm{NG}$ & -970.75 & \\
\hline W3 & 6.45 & 5.38 & 4.03 & 3.00 & NG & $\mathrm{NG}$ & $\mathrm{NG}$ & -861.83 & \\
\hline
\end{tabular}

Note: OK indicates okay/acceptable performance level; NG indicates not good.

Note: IO is immediate occupancy; LS is life safety, CP is collapse prevention and NC is near collapse

Table 10. Reinforcing location

\begin{tabular}{llll}
\hline Rehabilitation method & Wall & Brace & Column \\
\hline MC-1 & Left bottom & Left bottom & $1 \mathrm{st}$ floor \\
CC-1 & Right top & Right top & 1 st floor \\
MC-2 & All of exterior & All of exterior & 1 st floor \\
CC-2 & Top exterior & Middle & 1 st floor \\
\hline
\end{tabular}

Therefore, further analysis, i.e., nonlinear analysis as a third assessment, may be required according to the specifications. However, this study does not include a third assessment. 


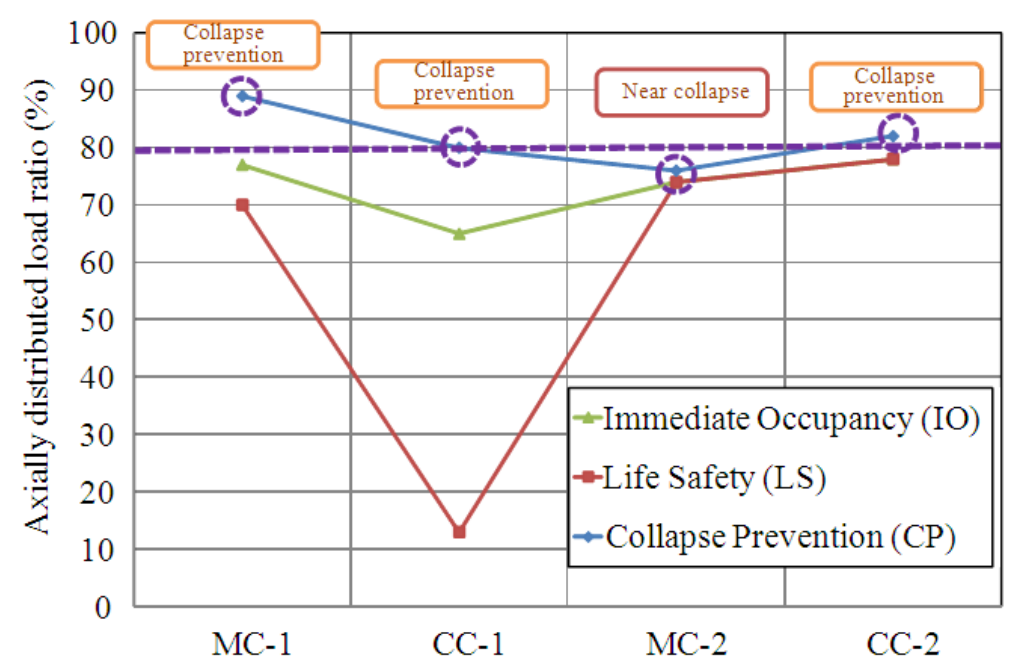

Fig. 3. Second seismic assessment results for each structure

\section{Rehabilitation Methods}

For the MC-1 structure, Fig. 4 shows three possible reinforcing locations for walls. The shear strength at the bottom of the structure and the displacement for each storey were used to determine the reinforcing location. The results of the first and second assessments indicate that the $\mathrm{x}$-directional capacity is considerably less than the y-direction capacity, so a RC shear wall with a thickness of $200 \mathrm{~mm}$ was installed at the bottom left corner, as seen in Fig. 4.

As a second possible reinforcing method, steel braces $(\mathrm{H}-250 \times 250 \times 9 \times 14)$ were installed at the same locations with a shear wall. Figure 5 shows three reinforcing locations for this second reinforcing method.

As a third possible reinforcing method, Fig. 6 shows three different reinforced locations for columns, including exterior columns, highly compressed columns and columns in the first floor. The cross-sections of the selected columns are increased by $20 \%$. Only the last case, i.e., where all the columns in the first floor are reinforced, attains the desired performance level.

For the MC-2 and CC-2 structures, the same methods were used to determine the reinforcing locations for the three types of rehabilitation. The final reinforcing methods for all four structures are summarized in Table 10.

\section{Seismic Assessment after Rehabilitation}

\section{First Seismic Assessment}

Figure 7 presents comparisons of the first seismic assessment results before rehabilitation and after reinforcement in the $\mathrm{x}$-and $\mathrm{y}$-directions using walls, braces and columns. The first assessment was conducted without reinforcing braces, so the first assessment results for MC-2 and CC-2 in terms of reinforcing braces are not included. For MC-1, the performance in the $\mathrm{x}$-direction is seen to be not as good as in the y-direction. However, both reinforcing methods are shown to attain the desired performance level of life safety. For the x-direction, the performance was improved to the life safety level using the reinforcing column method and to the immediate occupancy level using the reinforcing wall method. Both reinforcing methods provided sufficient strengthening. For the case of $\mathrm{CC}-1$, the seismic performance in both the $\mathrm{x}$ - and $\mathrm{y}$-directions is similar. With the use of a reinforcing column and wall, the performance was improved to the level of life safety. The performance of $\mathrm{MC}-2$ and $\mathrm{CC}-2$ improved from life safety to immediate occupancy for the x-direction.

The reinforcing column method shows better results than the reinforcing wall method for the y-direction.

\section{Second Seismic Assessment}

The goal of seismic rehabilitation is to attain the level of life safety in the second assessment. The second assessment results for each structures are presented with respect to each reinforcing method. Table 11 to 13 shows the second assessment results for MC-1 with respect to each reinforcing method, i.e., wall, brace and column, respectively.

The performance levels reached the level of immediate occupancy with the rehabilitation column method and the level of life safety with the rehabilitation brace and wall. Table 13 shows that the DCR values decreased for members that have an axially distributed load. If the current rehabilitation method is not satisfactory for the desired performance level, the column with an increase of cross-section reduces the DCR values of the walls, which decreases the axially distributed load. Overall, the most effective rehabilitation method is column rehabilitation. 

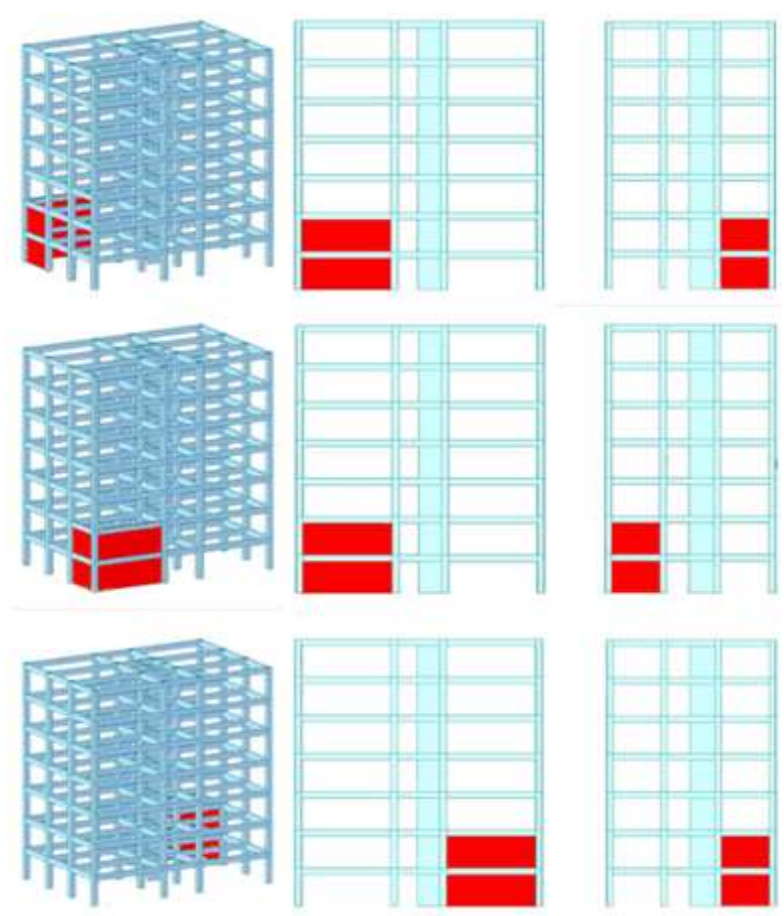

Fig. 4. MC-1 with respect to location of rehabilitation wall
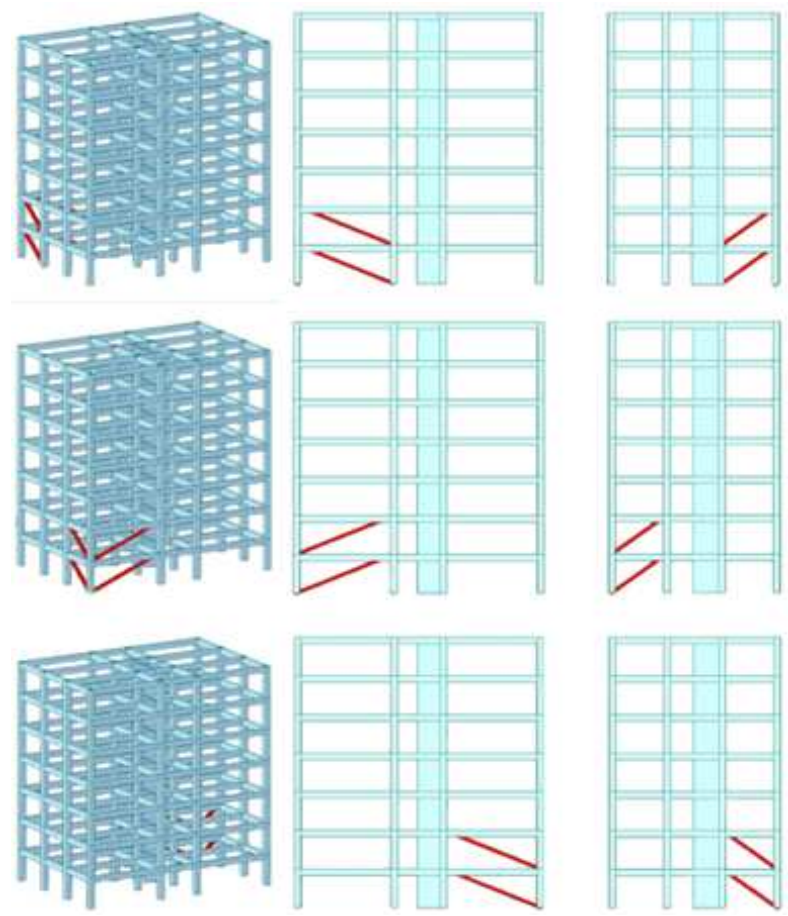

Fig. 5. MC-1 with respect to location of rehabilitation braces

Figure 8 presents comparisons of the desired performance levels for each rehabilitation method. Figure $8 \mathrm{a}$ shows that $\mathrm{MC}-1$ is at a level of collapse prevention. All three reinforcing methods reach the desired performance level of life safety.
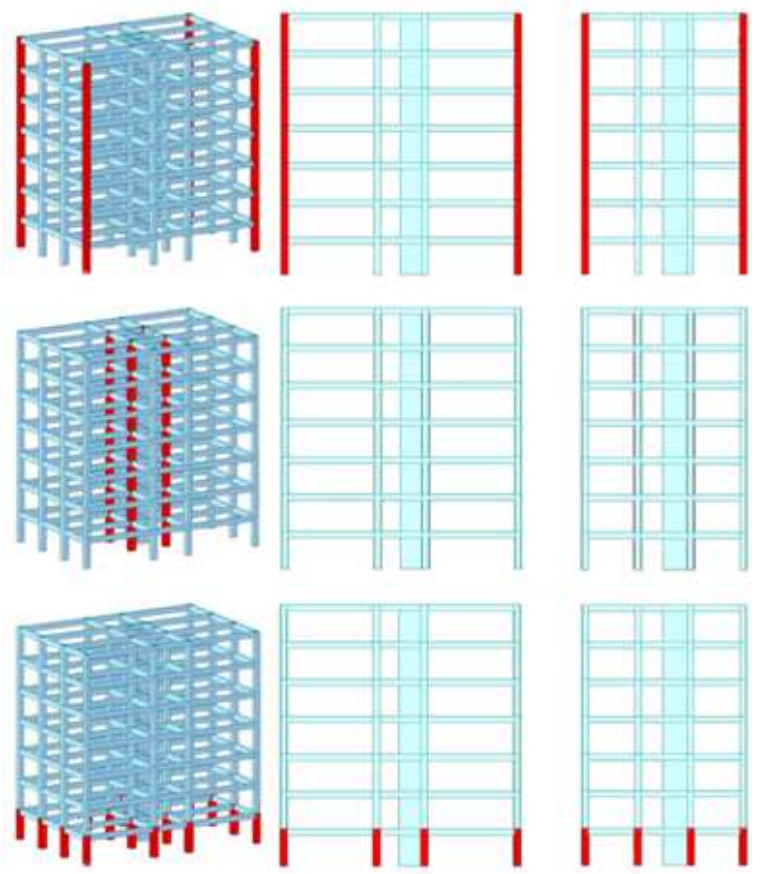

Fig. 6. MC-1 with respect to the location of rehabilitation columns

Figure $8 \mathrm{~b}$ indicates that the seismic assessment level for MC-2 is near collapse before rehabilitation, although the desired performance level (life safety) is obtained regardless of the rehabilitation method. The seismic performance with the rehabilitation wall was at the levels of immediate occupancy and life safety and the seismic performance with the rehabilitation column and brace was at levels of life safety. The seismic performance improved in the order of rehabilitation wall $>$ rehabilitation column $>$ rehabilitation brace, because performance improved with an increase in the axially distributed load ratio. The use of the brace and column for rehabilitation reduced the axial load carried by the existing column member. Specifically, the rehabilitation wall show edsuperior performance by significantly reducing the axial load. For the case of a structure with a relatively large core wall, the wall carries more axial load than the column, which improves the seismic performance level significantly. In the case of $\mathrm{MC}-2$, the core wall is located in the center of the structure so that there is no concerns, unless the newly installed wall is located in corner. The rehabilitation wall is the most effective method for this structure.

Figure 8c shows that $\mathrm{CC}-1$ is at a level of collapse prevention prior to rehabilitation. The performance after rehabilitation meets the desired level of life safety regardless of the rehabilitation method. The axial load distributions are similar for the three rehabilitation methods. However, the DCR values in Table 11 to 13 show a radical decrease. Specifically, the performance of the wall improved with the reduction of the axial load distribution after rehabilitation wall reinforcement. 

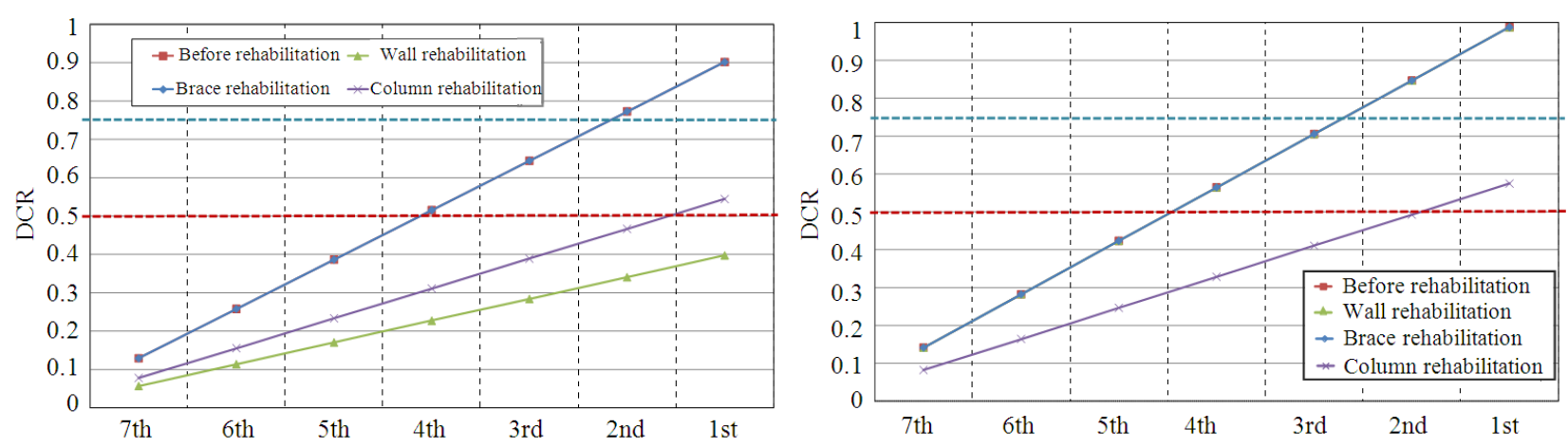

Fig. 7. Comparison of seismic assessment results before and after reinforcing

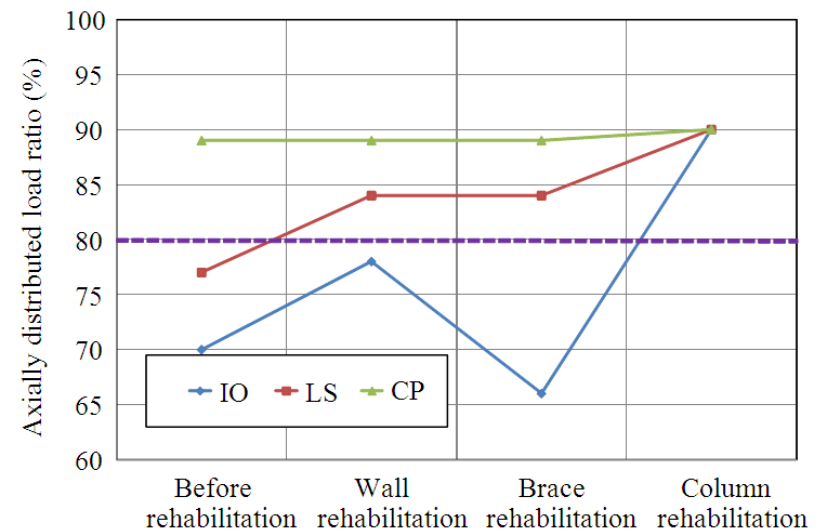

(a)

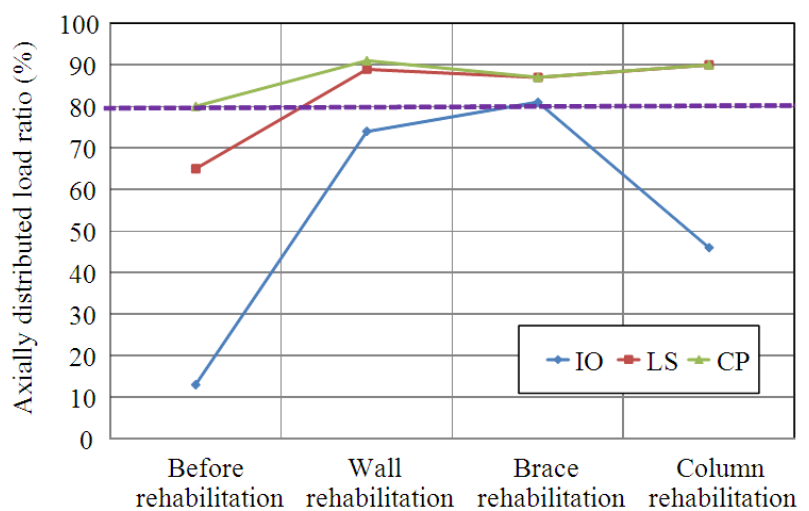

(c)

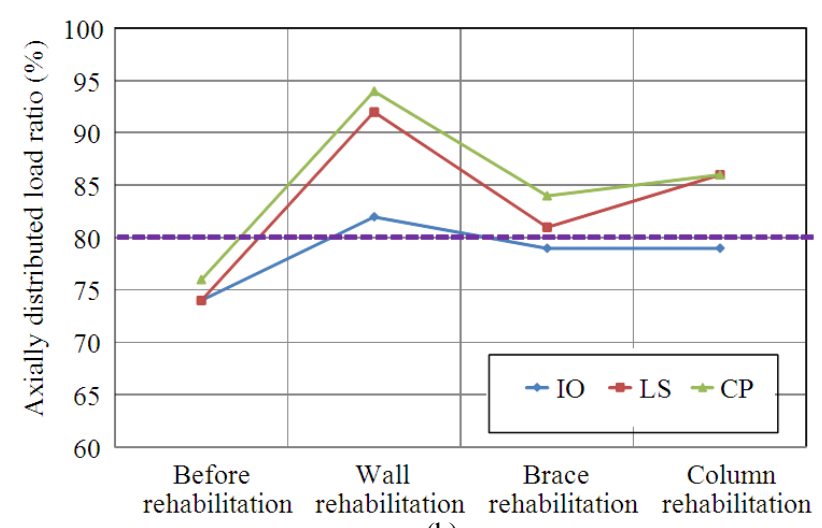

(b)

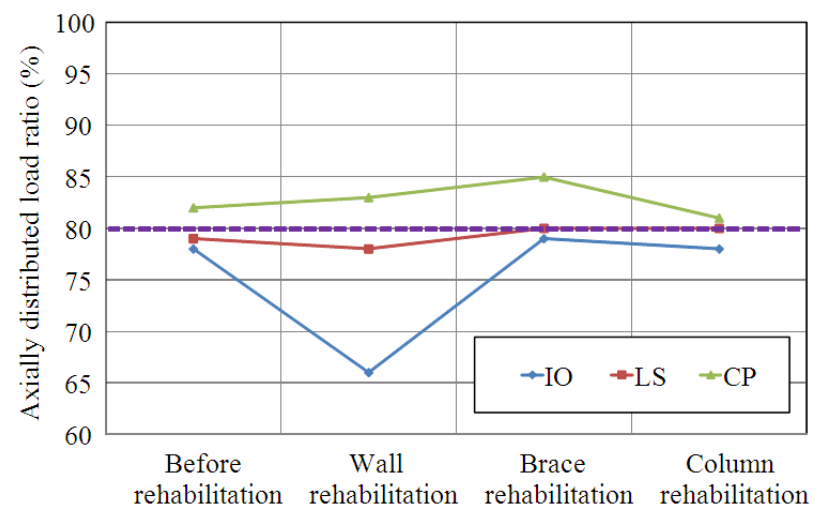

(d)

Fig. 8. Performance level for each structure, (a) MC-1, (b) MC-2, (c) CC-1, (d) CC-2

Overall, the rehabilitation brace is the most effective form of reinforcement because the installed braces take over the axial loads of the adjacent column. In short, consideration of the DCR of the column might be effective when installing braces.

Figure $8 \mathrm{~d}$ shows that $\mathrm{CC}-2$ was at a level of collapse prevention prior to rehabilitation. However, the rehabilitation brace and column methods improved the performance level to life safety. Similar to MC-2, the core area of CC-2 is $10 \%$ of the total area and is located on the lower part on the floor plan. To make the section symmetrical, the rehabilitation area was located in the upper part of the floor plan. Therefore, the axial load distribution changed.

The distribution factor of the axial load of the existing wall decreased and the performance decreased considerably to the immediate occupancy level due to the increase of the distribution factor on the existing column. 
Taek-Hyun Lee et al. / American Journal of Applied Sciences 2014, 11 (11): 1892.1903 DOI: 10.3844/ajassp.2014.1892.1903

Table 11. Second seismic assessment of MC-1 after reinforcement with rehabilitation wall

\begin{tabular}{|c|c|c|c|c|c|c|c|c|c|}
\hline \multirow[b]{2}{*}{ ID } & \multicolumn{4}{|c|}{ DCR values } & \multicolumn{4}{|c|}{ Desired performance level } & \multirow{2}{*}{$\begin{array}{l}\text { Axially } \\
\text { distributed } \\
\text { load ratio }\end{array}$} \\
\hline & IO & LS & $\mathrm{CP}$ & $\mathrm{NC}$ & LS & CP & $\mathrm{NC}$ & $\mathrm{P},(\mathrm{kN})$ & \\
\hline $\bar{C} 31$ & 0.73 & 0.73 & 0.49 & 0.10 & $\mathrm{OK}$ & $\mathrm{OK}$ & $\mathrm{OK}$ & -1790 & LS: $78 \%$ \\
\hline $\mathrm{C} 32$ & 0.60 & 0.60 & 0.40 & 0.38 & $\mathrm{OK}$ & $\mathrm{OK}$ & $\mathrm{OK}$ & -2025 & $(\mathrm{NG})$ \\
\hline $\mathrm{C} 33$ & 1.81 & 1.81 & 1.20 & 0.56 & NG & NG & $\mathrm{OK}$ & -1191 & \\
\hline C34 & 1.09 & 1.09 & 0.73 & 0.63 & NG & $\mathrm{OK}$ & $\mathrm{OK}$ & -1656 & CP: $84 \%$ \\
\hline $\mathrm{C} 35$ & 0.58 & 0.58 & 0.38 & 0.27 & $\mathrm{OK}$ & $\mathrm{OK}$ & $\mathrm{OK}$ & -1598 & $(\mathrm{OK})$ \\
\hline $\mathrm{C} 36$ & 0.54 & 0.54 & 0.36 & 0.39 & $\mathrm{OK}$ & $\mathrm{OK}$ & $\mathrm{OK}$ & -1551 & \\
\hline C37 & 0.55 & 0.55 & 0.37 & 0.37 & $\mathrm{OK}$ & $\mathrm{OK}$ & $\mathrm{OK}$ & -1565 & $\mathrm{~V}: 89 \%$ \\
\hline C 38 & 0.54 & 0.54 & 0.36 & 0.37 & $\mathrm{OK}$ & $\mathrm{OK}$ & $\mathrm{OK}$ & -1586 & $(\mathrm{OK})$ \\
\hline C39 & 0.56 & 0.56 & 0.38 & 0.36 & $\mathrm{OK}$ & $\mathrm{OK}$ & $\mathrm{OK}$ & -1337 & \\
\hline $\mathrm{C} 40$ & 0.59 & 0.59 & 0.39 & 0.36 & $\mathrm{OK}$ & $\mathrm{OK}$ & $\mathrm{OK}$ & -1301 & \\
\hline C41 & 0.61 & 0.61 & 0.41 & 0.08 & $\mathrm{OK}$ & $\mathrm{OK}$ & $\mathrm{OK}$ & -627 & \\
\hline $\mathrm{C} 42$ & 0.55 & 0.55 & 0.37 & 0.33 & $\mathrm{OK}$ & $\mathrm{OK}$ & $\mathrm{OK}$ & -1323 & \\
\hline C43 & 0.55 & 0.55 & 0.37 & 0.30 & $\mathrm{OK}$ & $\mathrm{OK}$ & $\mathrm{OK}$ & -934 & \\
\hline C44 & 0.54 & 0.54 & 0.36 & 0.28 & $\mathrm{OK}$ & $\mathrm{OK}$ & $\mathrm{OK}$ & -937 & \\
\hline $\mathrm{C} 45$ & 0.92 & 0.92 & 0.62 & 0.20 & $\mathrm{OK}$ & $\mathrm{OK}$ & $\mathrm{OK}$ & -394 & \\
\hline $\mathrm{C} 46$ & 0.54 & 0.54 & 0.36 & 0.27 & $\mathrm{OK}$ & $\mathrm{OK}$ & $\mathrm{OK}$ & -928 & \\
\hline W1 & 3.69 & 3.07 & 2.30 & 1.87 & $\mathrm{NG}$ & $\mathrm{NG}$ & $\mathrm{NG}$ & -907 & \\
\hline W2 & 4.91 & 4.09 & 3.07 & 3.04 & $\mathrm{NG}$ & $\mathrm{NG}$ & $\mathrm{NG}$ & -1025 & \\
\hline W3 & 4.79 & 3.99 & 3.00 & 1.17 & $\mathrm{NG}$ & $\mathrm{NG}$ & $\mathrm{NG}$ & -875 & \\
\hline
\end{tabular}

Table 12. Second seismic assessment of MC-1 after reinforcement with rehabilitation brace

\begin{tabular}{|c|c|c|c|c|c|c|c|c|c|}
\hline \multirow[b]{2}{*}{ ID } & \multicolumn{4}{|c|}{ DCR values } & \multicolumn{4}{|c|}{ Desired performance level } & \multirow{2}{*}{$\begin{array}{l}\text { Axially } \\
\text { distributed } \\
\text { load ratio }\end{array}$} \\
\hline & $\mathrm{IO}$ & LS & $\mathrm{CP}$ & $\mathrm{NC}$ & $\mathrm{LS}$ & $\mathrm{CP}$ & $\mathrm{NC}$ & $\mathrm{P},(\mathrm{kN})$ & \\
\hline C31 & 1.08 & 1.08 & 0.72 & 0.02 & $\mathrm{NG}$ & $\mathrm{OK}$ & $\mathrm{OK}$ & -1791 & LS: $66 \%$ \\
\hline $\mathrm{C} 32$ & 0.65 & 0.65 & 0.43 & 0.39 & $\mathrm{OK}$ & $\mathrm{OK}$ & $\mathrm{OK}$ & -2075 & $(\mathrm{NG})$ \\
\hline $\mathrm{C} 33$ & 1.8 & 1.8 & 1.2 & 0.56 & NG & NG & $\mathrm{OK}$ & -1181 & \\
\hline C34 & 1.06 & 1.06 & 0.71 & 0.63 & NG & $\mathrm{OK}$ & $\mathrm{OK}$ & -1675 & CP: $84 \%$ \\
\hline C35 & 0.59 & 0.59 & 0.39 & 0.44 & $\mathrm{OK}$ & $\mathrm{OK}$ & $\mathrm{OK}$ & -1597 & $(\mathrm{OK})$ \\
\hline C36 & 0.58 & 0.58 & 0.39 & 0.44 & $\mathrm{OK}$ & $\mathrm{OK}$ & $\mathrm{OK}$ & -1601 & \\
\hline C 37 & 0.53 & 0.53 & 0.35 & 0.36 & $\mathrm{OK}$ & $\mathrm{OK}$ & $\mathrm{OK}$ & -1563 & $\mathrm{~V}: 89 \%$ \\
\hline C 38 & 0.53 & 0.53 & 0.35 & 0.34 & $\mathrm{OK}$ & $\mathrm{OK}$ & $\mathrm{OK}$ & -1586 & $(\mathrm{OK})$ \\
\hline C39 & 0.58 & 0.58 & 0.38 & 0.37 & $\mathrm{OK}$ & $\mathrm{OK}$ & $\mathrm{OK}$ & -1332 & \\
\hline $\mathrm{C} 40$ & 0.58 & 0.58 & 0.39 & 0.36 & $\mathrm{OK}$ & $\mathrm{OK}$ & $\mathrm{OK}$ & -1290 & \\
\hline C41 & 0.85 & 0.85 & 0.57 & 0.03 & $\mathrm{OK}$ & $\mathrm{OK}$ & $\mathrm{OK}$ & -1325 & \\
\hline $\mathrm{C} 42$ & 0.56 & 0.56 & 0.37 & 0.33 & $\mathrm{OK}$ & $\mathrm{OK}$ & $\mathrm{OK}$ & -1355 & \\
\hline $\mathrm{C} 43$ & 0.56 & 0.56 & 0.37 & 0.34 & $\mathrm{OK}$ & $\mathrm{OK}$ & $\mathrm{OK}$ & -925 & \\
\hline $\mathrm{C} 44$ & 0.55 & 0.55 & 0.37 & 0.27 & $\mathrm{OK}$ & $\mathrm{OK}$ & $\mathrm{OK}$ & -935 & \\
\hline $\mathrm{C} 45$ & 1.32 & 1.32 & 0.88 & 0.03 & $\mathrm{NG}$ & $\mathrm{OK}$ & $\mathrm{OK}$ & -1005 & \\
\hline C46 & 0.53 & 0.53 & 0.35 & 0.25 & $\mathrm{OK}$ & $\mathrm{OK}$ & $\mathrm{OK}$ & -928 & \\
\hline W1 & 4.46 & 3.72 & 2.79 & 2.32 & $\mathrm{NG}$ & $\mathrm{NG}$ & $\mathrm{NG}$ & -853 & \\
\hline W2 & 4.91 & 4.09 & 3.07 & 3.05 & $\mathrm{NG}$ & $\mathrm{NG}$ & $\mathrm{NG}$ & -995 & \\
\hline W3 & 4.75 & 3.96 & 2.97 & 1.65 & NG & $\mathrm{NG}$ & $\mathrm{NG}$ & -837 & \\
\hline
\end{tabular}

Table 13. Second seismic assessment of MC-1 after reinforcement with rehabilitation column

\begin{tabular}{|c|c|c|c|c|c|c|c|c|c|}
\hline \multirow[b]{2}{*}{ ID } & \multicolumn{4}{|c|}{ DCR values } & \multicolumn{4}{|c|}{ Desired performance level } & \multirow{2}{*}{$\begin{array}{l}\text { Axially } \\
\text { distributed } \\
\text { load ratio }\end{array}$} \\
\hline & $\mathrm{IO}$ & LS & $\mathrm{CP}$ & $\mathrm{NC}$ & $\mathrm{LS}$ & $\mathrm{CP}$ & $\mathrm{NC}$ & $\mathrm{P},(\mathrm{kN})$ & \\
\hline$\overline{\mathrm{C} 31}$ & 0.66 & 0.66 & 0.44 & 0.22 & $\mathrm{OK}$ & $\overline{\mathrm{OK}}$ & OK & -1867 & LS: $90 \%$ \\
\hline $\mathrm{C} 32$ & 0.43 & 0.43 & 0.29 & 0.09 & $\mathrm{OK}$ & $\mathrm{OK}$ & $\mathrm{OK}$ & -2109 & $(\mathrm{OK})$ \\
\hline $\mathrm{C} 33$ & 0.69 & 0.69 & 0.46 & 0.04 & $\mathrm{OK}$ & $\mathrm{OK}$ & $\mathrm{OK}$ & -1363 & \\
\hline C34 & 0.52 & 0.52 & 0.35 & 0.08 & $\mathrm{OK}$ & $\mathrm{OK}$ & $\mathrm{OK}$ & -1730 & CP: $90 \%$ \\
\hline $\mathrm{C} 35$ & 0.54 & 0.54 & 0.36 & 0.37 & $\mathrm{OK}$ & $\mathrm{OK}$ & $\mathrm{OK}$ & -1615 & $(\mathrm{OK})$ \\
\hline C 36 & 0.57 & 0.57 & 0.38 & 0.34 & $\mathrm{OK}$ & $\mathrm{OK}$ & $\mathrm{OK}$ & -1615 & \\
\hline C37 & 0.51 & 0.51 & 0.34 & 0.20 & $\mathrm{OK}$ & $\mathrm{OK}$ & $\mathrm{OK}$ & -1579 & $\mathrm{~V}: 90 \%$ \\
\hline C38 & 0.55 & 0.55 & 0.37 & 0.21 & $\mathrm{OK}$ & $\mathrm{OK}$ & $\mathrm{OK}$ & -1600 & $(\mathrm{OK})$ \\
\hline C39 & 0.46 & 0.46 & 0.30 & 0.79 & $\mathrm{OK}$ & $\mathrm{OK}$ & $\mathrm{OK}$ & -1347 & \\
\hline $\mathrm{C} 40$ & 0.46 & 0.46 & 0.31 & 0.78 & $\mathrm{OK}$ & $\mathrm{OK}$ & $\mathrm{OK}$ & -1303 & \\
\hline C41 & 0.56 & 0.56 & 0.37 & 0.14 & $\mathrm{OK}$ & $\mathrm{OK}$ & $\mathrm{OK}$ & -1373 & \\
\hline $\mathrm{C} 42$ & 0.57 & 0.57 & 0.38 & 0.01 & $\mathrm{OK}$ & $\mathrm{OK}$ & $\mathrm{OK}$ & -1361 & \\
\hline $\mathrm{C} 43$ & 0.44 & 0.44 & 0.30 & 0.32 & $\mathrm{OK}$ & $\mathrm{OK}$ & $\mathrm{OK}$ & -931 & \\
\hline C44 & 0.42 & 0.42 & 0.28 & 0.17 & $\mathrm{OK}$ & $\mathrm{OK}$ & $\mathrm{OK}$ & -925 & \\
\hline $\mathrm{C} 45$ & 0.52 & 0.52 & 0.35 & 0.23 & $\mathrm{OK}$ & $\mathrm{OK}$ & $\mathrm{OK}$ & -936 & \\
\hline C46 & 0.50 & 0.50 & 0.33 & 0.13 & $\mathrm{OK}$ & $\mathrm{OK}$ & $\mathrm{OK}$ & -930 & \\
\hline W1 & 5.30 & 4.42 & 3.31 & 2.68 & NG & $\mathrm{NG}$ & NG & -733 & \\
\hline W2 & 4.32 & 3.60 & 2.70 & 2.75 & $\mathrm{NG}$ & $\mathrm{NG}$ & $\mathrm{NG}$ & -838 & \\
\hline W3 & 5.34 & 4.45 & 3.34 & 1.87 & NG & $\mathrm{NG}$ & $\mathrm{NG}$ & -810 & \\
\hline
\end{tabular}




\begin{tabular}{|c|c|c|c|c|c|c|c|c|}
\hline \multicolumn{3}{|c|}{ Before rehabilitation } & \multicolumn{2}{|c|}{ Brace $(\%)$} & \multicolumn{2}{|c|}{ Column (\%) } & \multicolumn{2}{|c|}{ Wall (\%) } \\
\hline \multirow[t]{3}{*}{ MC-1 } & $\mathrm{CP}$ & LS 70 & LS & LS 66 & $\mathrm{IO}$ & LS 90 & LS & LS 78 \\
\hline & & CP 77 & & CP 84 & & CP 90 & & CP 84 \\
\hline & & NC 89 & & NC 89 & & NC 90 & & NC 89 \\
\hline \multirow[t]{3}{*}{ MC-2 } & $\mathrm{NC}$ & LS 74 & $\mathrm{LS}$ & LS 79 & LS & LS 79 & $\mathrm{IO}$ & LS 82 \\
\hline & & CP 74 & & CP 81 & & CP 86 & & CP 92 \\
\hline & & NC 76 & & NC 84 & & NC 86 & & NC 94 \\
\hline \multirow[t]{3}{*}{$\mathrm{CC}-1$} & $\mathrm{CP}$ & LS 13 & IO & LS 81 & LS & LS 46 & $\mathrm{LS}$ & LS 74 \\
\hline & & СР 65 & & CP 87 & & CP 90 & & CP 89 \\
\hline & & NC 80 & & NC 87 & & NC 90 & & NC 91 \\
\hline \multirow[t]{3}{*}{$\mathrm{CC}-2$} & $\mathrm{CP}$ & LS 78 & LS & LS 79 & LS & LS 78 & $\mathrm{CP}$ & LS 66 \\
\hline & & CP 79 & & CP 80 & & CP 80 & & CP 78 \\
\hline & & NC 82 & & NC 85 & & NC 81 & & NC 83 \\
\hline
\end{tabular}

Table 14 presents the overall results of the second seismic assessment after rehabilitation. If the desired capacity of mid-sized structures with RC frames with core walls is the level of life safety, then the three proposed rehabilitation methods (i.e., braces, columns, walls) all are effective.

However, the axial load distribution for the reinforcing wall could change in the case of a relatively large core located on the side of the structure. If the desired performance level is immediate occupancy, then the reinforcing column for $\mathrm{MC}-1$, reinforcing brace for $\mathrm{CC}-1$ and reinforcing wall for $\mathrm{CC}-2$ are appropriate reinforcements, except for $\mathrm{CC}-2$, which is not suitable for the proposed reinforcing methods.

\section{Conclusion}

This study examined the seismic assessment of nonseismically designed RC structures in terms of the deterioration of the structure with age. After rehabilitation reinforcements using bearing walls, braces and columns, seismic assessments of the RC structures were conducted. The following conclusions are drawn based on the results of this study.

Most non-seismically designed RC frame structures with core walls in Korea fail the life safety level in terms of seismic performance. Most structures perform poorly and are at the collapse prevention and/or collapse level.

To enhance the seismic performance of these structures, reinforcing methods, such as installing braces, reinforcing walls and adding columns could be effective in increasing the seismic capacity of the structure. The effectiveness of each reinforcing method depends on the size of the structure, its floor plan, constructability and cost evaluation.

In the case of a core wall in the middle of a structure, the reinforced column is a good rehabilitation method for a small area of the core wall, whereas the reinforced wall is more efficient for a large area of core wall.

In the case of a core wall located at the side of a structure, the reinforced brace is the most efficient rehabilitation method to enhance overall seismic performance.
With regard to the reinforcement column as a rehabilitation method, the livability of the structure should be considered to determine the size of the cross-section and then reinforcement in the lower elevation of the structure is more economical than in the higher elevation.

\section{Funding Information}

This study reported here was financially supported by the General Researcher Support Program through the National Research Foundation (NRF-20110010916).

\section{Author's Contributions}

All authors equally contributed in this work.

\section{Ethics}

This article is original and contains unpublished materials. The corresponding author confirms that all of the other authors have read and approved the manuscript and no ethical issues involved.

\section{References}

Adebar, P. and T. White, 2002. Seismic design of high-rise coupled wall buildings: Ductility of coupling beams. Proceeding of the 7th US Conference on Earthquake Engineering, (CEE' 02), Boston, USA.

Adebar, P., 2005. High-rise concrete wall buildings: Utilizing unconfined concrete for seismic resistance. Proceedings of the Con Mat'05 International Conference, (MIC' 05), Vancouver, Canada.

Adebar, P., 2008. Design of high-rise core-wall buildings: A Canadian perspective. Proceedings of the 14th World Conference on Earthquake Engineering, Oct. 12-17, Beijing, China.

ASCE, 2003. Seismic evaluation of existing buildings. American Society of Civil Engineers, Reston, Virginia. 
ASCE, 2006. Seismic rehabilitation of existing buildings. American Society of Civil Engineers, Reston, Virginia.

FEMA, 1997. Guidelines to the seismic rehabilitation of existing buildings. Federal Emergency Management Agency, Washington, D.C.

FEMA, 2000. Prestandard and commentary for the seismic rehabilitation of buildings. Federal Emergency Management Agency, Washington, D.C.

Kang, J., 2011. Seismic performance evaluation according to retrofit techniques of nonseismically designed shear wall type apartment. J. Korean Society Hazard Mitigat., 11: 39-44.
Kim, H.D., 2011. Structure evaluating of existing building seismic retrofit. MSc., Thesis, Kyungpook National University.

KISC, 2011. Seismic Assessment Methods of Existing Buildings. 1st Edn., Korean Infrastructure Safety Corporation, pp: 115.

Lee, T.H. 2013. Seismic performance evaluation and retrofit of middle and low-rise building with core wall. MSc. Thesis, Gachon University.

NEMA, 2012. Guidelines to the Seismic Assessment of Buildings. 1st Edn., National Emergency Management Agency, pp: 150. 